\title{
INTEgRATIVE THEORY OF THE MODE OF ACTION OF QUINCLORAC: LITERATURE REVIEW ${ }^{1}$
}

\author{
Teoria Integradora sobre o Modo de Ação de Quinclorac: Revisão de Literatura
}

FIPKE, M.V. ${ }^{2}$, and VIDAL R.A. ${ }^{2}$

\begin{abstract}
Quinclorac is a systemic herbicide absorbed by germinating seeds, roots and leaves of seedlings. It is a selective compound for crops such as rice, canola, barley, corn, sorghum, and pasture. Quinclorac can be used to control various monocots and dicotyledonous weed species. The biochemical function of this herbicide in the plant has intrigued scientists for nearly four decades. The objectives of this review are to present evidence of three hypotheses on the biochemical functioning of quinclorac and to propose an integrative mode of action. The first theory on the mode of action of quinclorac is supported by evidence of inhibition of incorporation of $\mathrm{C}^{14}$-glucose into cellulose and hemicellulose, thus, affecting the cell wall synthesis. The second hypothesis suggests that quinclorac acts as an auxin in broadleaved weed species. In grass species, however, this herbicide appears to stimulate the activity of the 1-aminocyclopropane-1-carboxylate synthase enzyme and, subsequently, to increase the ethylene production; also, it seems to increase the cyanide acid content to phytotoxic levels. A third hypothesis to explain the harmful effect in some plant species is the formation of reactive oxygen species (ROS). Apparently, these processes are not mutually exclusive; therefore, an integrative theory for the action of quinclorac is suggested. It is theorized that the aforementioned biochemical activities are interconnected and can be the phytotoxic backbone to explain the herbicidal effect depending on the plant species and the plant growth stage, among other factors.
\end{abstract}

Keywords: cellulose biosynthesis-inhibitor, cyanide, auxinic herbicide, reactive oxygen species.

RESUMO - O quinclorac é um herbicida sistêmico absorvido por sementes em germinação, raizes e folhas de plântulas. Ele é um produto seletivo para as culturas de arroz, canola, cevada, milho, pastagens e sorgo. Ele pode ser utilizado no controle de diversas plantas daninhas dicotiledôneas e monocotiledôneas. O funcionamento bioquimico desse herbicida na planta tem intrigado os cientistas por quase duas décadas. Os objetivos desta revisão foram apresentar evidências de três hipóteses sobre o funcionamento bioquimico do quinclorac e, a partir das evidências existentes, propor um modo de ação integrador. A primeira teoria sobre o modo de ação do quinclorac é apoiada por evidências de inibição da incorporação de glicose em celulose e em hemiceluloses, afetando assim a sintese de parede celular. A segunda hipótese sugere que o quinclorac atua como auxina sintética em espécies dicotiledôneas. Em espécies gramineas, todavia, sua ação parece envolver o estímulo da atividade da enzima ácido 1-carboxílico-1-aminociclopropano sintase e o aumento posterior da produção de etileno e, principalmente, cianeto em niveis fitotóxicos. Uma terceira hipótese evidencia que a ação do quinclorac em algumas espécies depende da formação de espécies reativas de oxigênio (ROS). Aparentemente esses processos não são excludentes, por isso é proposta uma teoria integradora para ação do quinclorac. Teoriza-se que as atividades bioquimicas citadas constituem o fundamento da ação desse herbicida e que a manifestação de determinada rota depende das espécies vegetais e dos estágios de desenvolvimento da planta, entre outros fatores.

Palavras-chave: inibidor da síntese de celulose, herbicida auxínico, cianeto, espécies reativas de oxigênio.

Recebido para publicação em 7.6.2015 e aprovado em 16.12.2015.

Universidade Federal do Rio Grande do Sul(UFRGS), Porto Alegre-RS, Brazil, <marfipke@gmail.com>.

Planta Daninha, Viçosa-MG, v. 34, n. 2, p. 393-402, 2016 


\section{INTRODUCTION}

Quinclorac (3.7-dichloro-8quinolinecarboxylic acid) (Figure 1) was introduced in 1992 on rice crops, and it was firstly used to control Echinochloa spp. (Talbert $\&$ Burgos, 2007). It is a systemic herbicide that may be absorbed by germinating seeds, roots and leaves, and it is translocated in the basipetal and acropetal forms. The apex of the plant and the young leaves are the major drains for the acropetal translocation of quinclorac (Bond \& Walker, 2012).

There is faster quinclorac absorption by the plant roots than by the leaves. After spraying quinclorac on Panicum repens, a greater absorption of the product was observed on the roots (Williams et al., 2004). Its translocation is mainly acropetal. After spraying quinclorac on $P$. repens leaves, it was observed that, within 48 to 72 hours, double the amount of the herbicide was found on the tip of the leaf blade in relation to the base of the leaf. On the roots, $46 \%$ of the absorbed product was translocated to the aerial part of the plant (Williams et al., 2004).

Quinclorac is highly selective for crops such as rice, canola, barley, corn, pasture and sorghum (Abdallah et al., 2006; Ferreira et al., 2012). It is used to control several dicotyledon weed plant species, such as Aeschynomene spp., Monochoria spp., Sesbania spp. and Trifolium spp., and monocotyledon species, such as Brachiaria spp., Digitaria spp., Echinochloa spp., Setaria viridis and Trifolium spp. (Grossman, 2010), including biotypes of Echinochloa spp. that are resistant to propanil (Talbert \& Burgos, 2007).

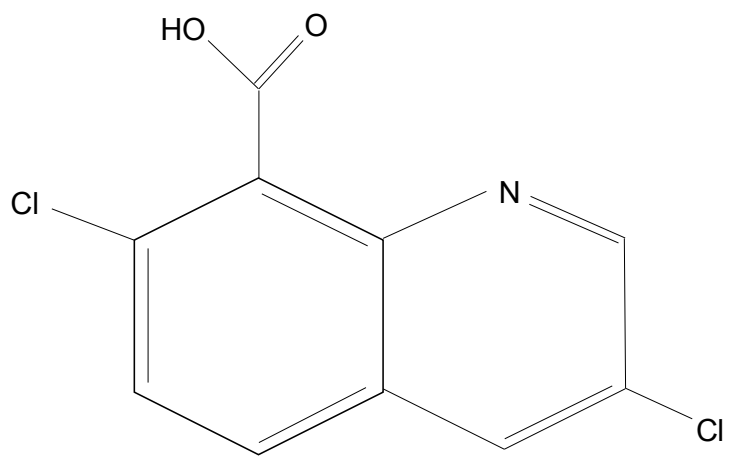

Figure 1 - Chemical structure of quinclorac.

Planta Daninha, Viçosa-MG, v. 34, n. 2, p. 393-402, 2016
In sensitive monocots, the symptoms of quinclorac occur between the seventh and the tenth day after the herbicide application. Initially, the plant growth is inhibited followed by the chlorosis of young leaves. Afterwards, the necrosis of the aerial part of plants occurs (Grossmann \& Kwiatkowski, 2000; Grossman, 2010). The effects on sensitive dicotyledon species are characterized by changes in growth, such as epinasty, and growth inhibition with intensification of the green pigmentation of leaves, which usually occurs within $24 \mathrm{~h}$. Then, damages to the chloroplast occur, consequently leading to chlorosis, destruction of the cell membranes and of the integrity of the vascular system, followed by leaf dehydration, tissue necrosis and death of the plants (Grossmann, 2000).

The mechanism of action is the primary biochemical target for the herbicide activity, whereas the mode of action is the sequence of events that accours afterwards and that leads to the plant death. Even after 20 years since the commercial release of quinclorac, there are still some controversies on its mode of action (Alonso-Simón et al., 2008). Among the likely modes of action of quinclorac are the inhibition of the cellular wall (Koo et al., 1996, 1997), auxinic action (Abdallah et al., 2006; Grossmann, 2010), in addition to the ability to stimulate the production of oxygen reactive species (ROS) (Sunohara et al., 2008, 2010). The objectives of this literature review were to show evidence of three hypotheses on the biochemical action of quinclorac and to suggest an integrative and innovative mode of action.

\section{MECHANISM AND MODE OF ACTION}

\section{Effect on the formation of the cellular wall}

Researches developed during the 1990's showed that quinclorac inhibits the glucose incorporation on the cellular wall, mainly for cellulose (Koo et al., 1996, 1997). When quinclorac was applied to Zea mays and Digitaria ischaemum, it inhibited their growth, changed the flow of electrons on young tissues and caused the tissue necrosis on the elongation zone of these monocots (Koo et al., 1994). Due to these symptoms and to other physiological responses, it was stated that 
these responses would be associated to the inhibition of the cellular expansion (Koo et al., 1996). Similar effects are found in other herbicides that inhibit cell wall synthesis, such as oxaziclomefone (O'Looney \& Fry, 2005) and diclobenil (Peng et al., 2001; DeBolt et al., 2007; Wightman \& Turner, 2010).

The primary cell wall is formed by cellulose microfibriles in a matrix of polysaccharides (pectins and hemicellulose) and structural proteins. Cellulose is synthesized by terminal complexes, which are located on the plasma membrane (Mansoori et al., 2014). These structures contain the cellulose synthases (enzymes that synthesize $\beta$-(1->4) D-glucanes; CESas). The role of CESas is to transfer glucose residues from a nucleotide to the glycan chain that is being formed (Paredez et al., 2006). Sterol-glycosides (sterols connected to a chain of two or three glucose residues) are the originators or the initial acceptors of the glycan formation (Peng et al., 2002). The sterol group is then removed from the glycan by endoglucanase. Then, the glycan chain moves through the membrane up to the outer part of the cell, where, together with other glycan chains, it is crystalized as a microfibril and interacts with hemicellulose and other matrix polysaccharides, originating the cell wall (Holland et al., 2000; Richmond \& Somerville, 2000).

The matrix is a highly hydrated phase, in which the cellulose microfibrils are implanted. The main matrix polysaccharides are synthesized on the Golgi complex lumen, and afterwards they are released to the apoplast through exocytosis of tiny vesicles (Driouich et al., 2012). The main enzymes responsible for the matrix synthesis are the ones from the glycosyltransferases family (Chevalier et al., 2010; Driouich et al., 2012). On the primary wall of dicotyledons, the main hemicellulose is xyloglucan (Bashline et al., 2014). On grass species, there are only small amounts of xyloglucan and pectin, however, there are high concentrations of glucuronoarabinoxylan (GAX) and $\beta-(1->3,1->4) \beta$-glucan (MG) (Thimm et al., 2002).

According to the physiology of the plant species (as described) and the concentration of quinclorac, the biosynthesis of the cellular wall may be inhibited (Koo et al., 1996). Three hours after the application of quinclorac on corn, it was observed that GAX and cellulose were notably inhibited, while MG was inhibited five hours after spraying (Koo et al., 1996). Acetate and thymidine were also inhibited on the incorporation of fatty acids and DNA, respectively (Koo et al., 1996). This data suggests that the biosynthesis of the cell wall may be the primary target location (mechanism of action) of quinclorac, whereas the subsequent inhibiting effects related to fatty acids and the DNA synthesis are probably secondary events (Koo et al., 1996). It was observed, also, that the biosynthesis of the cell wall of E. crus-galli and Digitaria sp. was inhibited in 73 and 60\%, respectively, after spraying quinclorac (Koo et al., 1997). This suggests that quinclorac shows similar effects than the ones of other cell wall inhibitors, such as diclobenil and isoxaben (Alonso-Simón et al., 2008).

These results are arguable. Indeed, 24 hours after the application of quinclorac, visible effects were not observed on the cellulose deposition on meristematic cells of the roots of Echinochloa crusgalli and corn (Tresch \& Grossmann, 2003). In opposition, the cellulose deposition on corn roots was inhibited after only four hours of the application of dichlobenil (a cellulose deposition inhibitor) (Tresch \& Grossmann, 2003).

Although quinclorac has inhibited the synthesis of MG on the root cells of corn and Echinochloa crusgalli (Koo et al., 1996; Tresch \& Grossmann, 2003), that may be due to an indirect effect of quinclorac through the biosynthesis of cyanide acid. With the application of cyanide acid, there was a reduction of MG deposition on the cellular walls of cells of the radicular meristem of Echinochloa crusgalli (Tresch \& Grossmann, 2003). Alternatively, it may be due to a secondary effect common to auxinic herbicides, possibly associated to the quick auxinic activity on $\beta$ glucans $(1 \rightarrow 3,1 \rightarrow 4)$ on the hydrolysis of the cellular wall matrix (Cosgrove, 2001).

After spraying quinclorac on common bean (Phaseolus vulgaris) grains, there was an increase on the glucose incorporation on the cellular wall (García-Ângulo et al., 2012). A similar effect was observed by spraying $2,4,5-\mathrm{T}$, thus, showing that quinclorac probably acts as 
an auxin and that the change to the pattern of glucose incorporation may be a side effect of its mode of action (García-Ângulo et al., 2012). In addition, the long-term changes to the cell wall caused by quinclorac on bean cells are not similar to the ones caused by other cell wall inhibitors, such as diclobenil or isoxaben (Alonso-Simón et al., 2008).

\section{Auxinic effect (including the production of cyanate)}

The mechanism of action of quinclorac has intrigued scientists for over two decades (Abdallah et al., 2006). There is a hypothesis that quinclorac acts as an auxin. Auxinic herbicides are known for connecting to auxin binding protein 1 (ABP1) and to other related proteins, leading to quick responses on the plant, such as ionic flow and cell expansion (Badescu \& Napier, 2006; Vanneste \& Friml, 2009). ABP1 may act as a coordinator for the cell division and expansion, and its activity is influenced by the auxin levels on the plasmalemma (Braun et al., 2008). Over the last decade, TIR1 proteins (transport inhibitor response 1 protein) and AFB (a protein that is homologous to TIR1) were identified as auxin receptors. The computer modeling of the TIR1 protein validated the hypothesis that quinclorac is perceived by the auxinic receptors, suggesting that this is the primary herbicide target (Dharmasiri et al., 2005; Grossmann, 2010).

Only the auxinic effect of quinclorac, however, is arguable. In corn plants (Zea mays), it was observed that quinclorac did not bind to ABP1 (Mito et al., 1991). Also, quinclorac did not acidify the growth medium of mung bean (Vigna radiata) tissues (Mito et al., 1990). In relation to this point, it is also not known whether the family of TIR 1 receptors responds to all the several signals from auxins and whether the biological activities that depend on the sensitivity of the tissue, physiological stage, biotype and species (Grossman, 2010). It is possible that differences of auxin sensitivity on these receptors among plant species would explain the selectivity paterns of auxinic herbicides (Grossman, 2010).

Researches suggest that, when TIR1 and/ or AFB perceive the auxin or the auxin mimic, they recognize the transcriptional repressor AUX/IAA, promoting their ubiquitination through the Skp1-cullin-F-box E3 ubiquitin ligase (SCF) protein (Dharmasiri et al., 2005; Kepinski \& Leyser, 2005). After the ubiquitination of AUX/IAA, degradation occurs through the ubiquitination-proteasome pathway (Dharmasiri et al., 2005; Kepinski \& Leyser, 2005). The loss of the transcriptional repressor AUX/IAA triggers the transcription activating proteins - the auxin response factors (ARFs). ARFs activate the transcription of genes that respond to auxin, including those that create ACS (1-aminocyclopropane-1carboxylate synthase acid) and 9-cisepoxycarotenoid dioxygenase (McMahon et al., 2000; Tan et al., 2007). These enzymes are fundamental on the biosynthesis pathways of ethylene and abscisic acid (ABA), respectively (Kraft et al., 2007; Grossmann, 2010).

The compound 1-aminocyclopropane1-carboxilic acid (ACC), catalyzed by ACO (1-aminocyclopropane-1-carboxilic acid oxidase), generates among other products: ethylene, $\mathrm{CO}_{2}$ and cyanate hydrogen ( $\left.\mathrm{HCN}\right)$. The increase on the ACC levels results in the action of ACO, leading to an accumulation of ethylene and cyanate (Figure 2) on the tissues (Sunohara et al., 2011). A hypothesis is that grass species sensitive to quinclorac do not have the ability to detoxify cyanate quickly, accumulating the product, which generates phytotoxic effects (Grossmann \& Kwiatkowski, 2000; Abdallah et al., 2006; Grossmann, 2010).

On E. crusgalli, it was observed that quinclorac acts mainly on radicular tissues (Grossmann, 2003), with ACS induction and accumulation of ACC. The excess of ACC is transported to shoot tissues, where ACO is stimulated, increasing the levels of ethylene, $\mathrm{CO}_{2}$ and $\mathrm{HCN}$ (Grossmann, 2010). This seems to be a self-amplification process, in which the accumulation of ACC and cyanate stimulates ACS (McMahon et al., 2000; Grossmann, 2010).

At 96 hours after spraying quinclorac, the concentration of cyanate increased from three up to nine times on the shoots of $D$. sanguinalis and E. crusgalli, in comparison to plants without herbicide application (Grossmann, 2003). After spraying quinclorac, the ethylene and cyanate levels on susceptible 


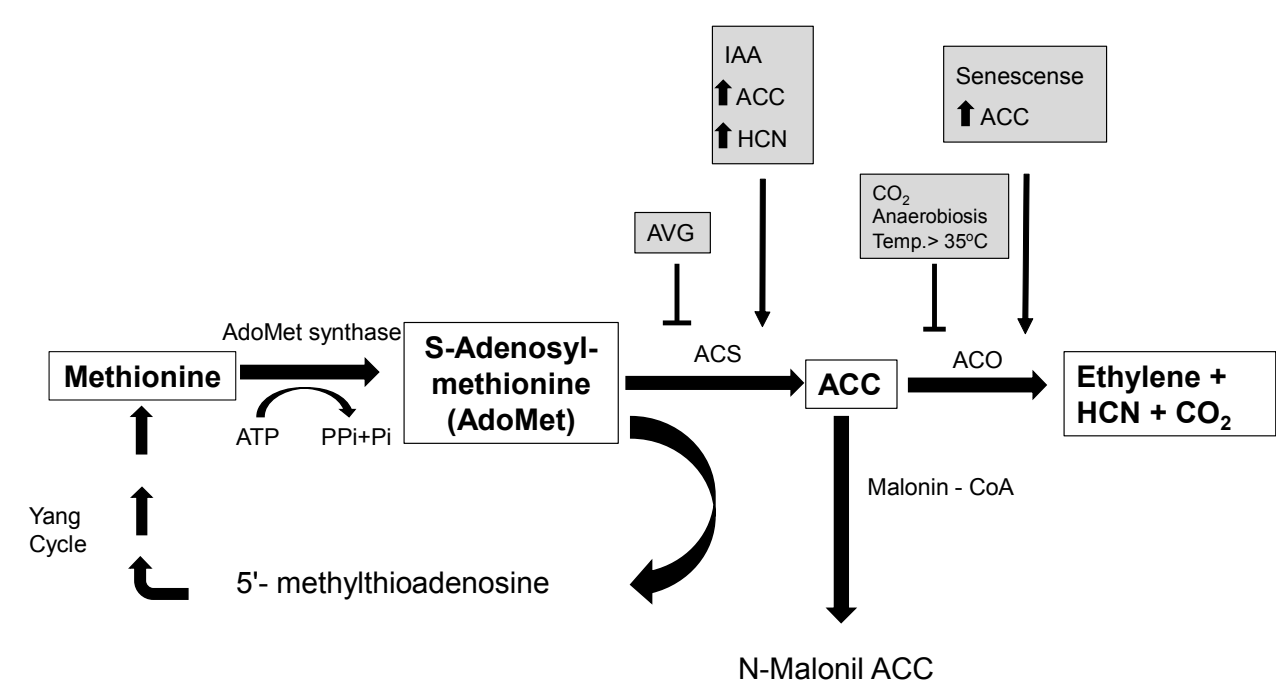

Modified from Taiz \& Zaiger (2006).

Figure 2 - Metabolic pathway of the ethylene synthesis.

D. ischaemum plants increased between four and eight times, respectively, in relation to the untreated controls (Abdallah et al., 2006). On plants that are resistant to the herbicide, no significant differences were observed (Abdallah et al., 2006). This suggests that the possible insensitivity of the enzyme to the effects of quinclorac may contribute to the resistance in plants.

Studies with $D$. ischaemum showed that the phytotoxic effects of quinclorac are caused by the accumulation of cyanate, originated from the stimulation of ACS on the shoots (Abdallah et al., 2006). With the exogenous application of potassium cyanate $(\mathrm{KCN})$ on $D$. ischaemum, the phytotoxic effects of quinclorac were reproduced, whichwere similar to the effects of the endogenous cyanate. Spraying the ACS aminoethoxyvinylglycine inhibitor on these plants, reduced the phytotoxic effects of quinclorac and the production of ethylene (Abdallah et al., 2006).

$\mathrm{HCN}$ is able to inhibit several important enzymes for plant metabolism, including $\mathrm{Cu} / \mathrm{Zn}$ superoxide dismutase, catalase, cytochrome-c oxidase, nitrate/nitrite reductase, nitrogenase and peroxidase (Grossman, 2003). High HCN levels may block the electron flow on the chloroplast and mitochondria, and it may lead to the formation of ROS and cell damage (Navrot et al., 2007). The key enzyme for the detoxification of cyanate is $\beta$ - cyanoalanine synthase ( $\beta$-CAS). This enzyme catalyzes the reaction of cysteine and cyanate to create hydrogen sulfide and $\beta$-cyanoalanine (Siegien \& Bogatek, 2006). The $\beta$-CAS activity is primarily located on the mitochondria, the most vulnerable organelle to the effects of HCN (Mayers \& Ahmad, 1991).

Plants with high $\beta$-CAS activity are resistant to the effects of cyanate (Liang, 2003). E. phyllopogon biotypes that showed high $\beta$-CAS levels were resistant to the effects of cyanate, triggered after spraying quinclorac (Yasuor et al., 2011). D. ischaemum plants resistant to quinclorac showed high $\beta$-CAS levels, in relation to the susceptible biotypes (Abdallah et al., 2006).

Spraying malation associated with quinclorac on E. phyllopogon plants decreased the resistance factor from 17 to 3 , in contrast to quinclorac alone (Yasuor et al., 2011). This result suggests that malation was able to inhibit the $\beta$-CAS activity on resistant E. phyllopogon plants, thus, inhibiting one of the main detoxification mechanisms of $\mathrm{HCN}$ (Yasuor et al., 2011).

Dicotyledons sensitive to quinclorac show no changes on the cyanate levels (Grossman, 2003). On this class of plants, an auxinic 
effect occurs and, later on, there is a higher production of ethylene, increasing ABA biosynthesis (Hansen \& Grossmann, 2000). Subsequently, ABA is distributed within the plant; on the leaves, stomata are closed, limiting the assimilation of carbon and, therefore, decreasing the biomass production (Grossmann, 2000; Hansen \& Grossmann, 2000). ABA accumulation leads to an excessive production of ROS, particularly hydrogen peroxide $\left(\mathrm{H}_{2} \mathrm{O}_{2}\right)$, causing cellular damage and leaf senescence (van Eerd et al., 2005; Grossmann, 2010).

Galium spurium plants that are resistant and susceptible to quinclorac showed no differences on the absorption, translocation, degradation and exudation of the herbicide. This indicates that other processes are involved on the resistance to these biotypes (van Eerd et al., 2005). After spraying quinclorac on $G$. spurium and $G$. aparine, it was observed an increase on the biosynthesis levels of ethylene and endogenous ABA on plants of the susceptible biotypes, in relation to the ones from the resistant biotypes (Grossmann et al., 2001; van Eerd et al., 2005). On resistant biotypes, there was no increase on the ethylene levels, however, they showed a three fold increment on the ABA levels, in comparison to the plants that were not sprayed with quinclorac; however, these levels were not enough to cause plant injury (van Eerd et al., 2005).

The explanation for this fact is that the mechanism of auxinic resistance may be due to alterations on the biding site and/or to a change in the transduction of the auxin signal (Grossmann, 2000). On susceptible G. spurium biotypes, it was suggested that quinclorac binds to a putative target site, which causes cascading events, such as the biosynthesis of ethylene and ABA, leading to the accumulation of $\mathrm{H}_{2} \mathrm{O}_{2}$ and, finally, causing plant death (van Eerd et al., 2005).

\section{Stimulation to the production of ROS}

The third hypothesis that would explain the quinclorac activity is related to its ability to induce the production of ROS, thus, suggesting that they would be responsible for the phytotoxic effects on susceptible grass plants (Sunohara et al., 2011). The accumulation of ROS inhibits the electron transportat during photosynthesis, promotes damages to the chlorophyll, damages proteins, membrane lipids and nucleic acids (Bowler et al., 1992; Sunohara \& Matsumoto, 2004). High production of ROS and subsequent events were observed on E. oryzicola (Sunohara \& Matsumoto, 2004), D. ascendens (Sunohara \& Matsumoto, 2010) and Zea mays (Sunohara \& Matsumoto, 2008).

On $Z$. mays roots, quinclorac $(50 \mu \mathrm{M})$ caused cell death, increased ethane production and incremented ethylene synthesis. The 2,4-D herbicide $(50 \mu \mathrm{M})$ showed no effect on cell death and ethane production, however, it increased ethylene prodution (Sunohara \& Matsumoto, 2008). After spraying quinclorac $(10 \mu \mathrm{M}), D$. adscendents showed high phytotoxicity and an increment on the ethylene production, in comparison to the untreated controls (Sunohara et al., 2010). These results indicate that the ethylene induced by quinclorac did not cause cell death or lipid peroxidation on corn roots cells of D. adscendents (Sunohara \& Matsumoto, 2008; Sunohara et al., 2010). In addition, cyanate is produced on stoichiometrically similar amount than ethylene (Peiser et al., 1984). The linear relation between the amount of the cyanate and ethylene contents were observed, for quinclorac and 2,4-D. Therefore, the cell death induced by quinclorac and the lipid peroxidation occurred on corn roots may not be explained by cyanate, but by the overproduction of ROS (Sunohara \& Matsumoto, 2008).

It is theorized that the plant tolerance to quinclorac is due to the higher production of ROS detoxifying enzymes (Sunohara et al., 2010). D. adscendents plants treated with quinclorac synthesized 3.4 times more antioxidant enzyme (superoxide anion scavenging activity, SOSA) than untreated plants, indicating that this process may be involved in the action of the herbicide (Sunohara et al., 2011). Eleusine indica plants showed high activity on the enzymatic protection system to eliminate ROS, suggesting that this process may be responsible for the tolerance to herbicides that induce the overproduction of ROS, such as 
quinclorac (Sunohara et al., 2011). Oryza sativa, Z. mays, E. crus-galli Beauv. var. crus-galli, E. crus-galli var. formosensis Ohwi and E. oryzicola Vasing plants showed a correlation between the sensitivity to quinclorac and the activity that constitutes antioxidant enzymes (Sunohara \& Matsumoto, 2004).

\section{Integrative theory}

Although there are several researches and studies conducted with quinclorac, there are still some uncertainties on its mechanism of action. On dicotyledons, it is likely that quinclorac shows auxinic action, acting on the biosynthesis of ethylene, ABA and ROS (Hansen \& Grossmann, 2000; van Eerd et al., 2005; Grossmann, 2010). On monocot plants, there are some controversies on its effect, and there is evidence of inhibition of the biosynthesis of the cellular wall (Koo et al., 1996; Koo et al., 1997), as well as ethylene and cyanate biosynthesis (McMahon et al., 2000; Abdallah et al., 2006; Grossmann, 2010), or even the overproduction of ROS (Sunohara \& Matsumoto, 2008; Sunohara et al., 2011).
On this review, we suggest an integrating hypothesis that associates all the processes described on the previous sections. Our interpretation is that quinclorac is a herbicide with multiple mechanisms of actions, in such a way that the final result of its activity is a combined result (not necessarily simultaneous or on the same vegetal tissues) of the inhibition of the cell wall synthesis, the auxinic action and the overproduction of ROS (Figure 3), as previously described.

Some questions still need to be cleared by the research, such as: whether or not there are quinclorac receptors on the plasma membrane of cells; the determination of the transport mechanism of quinclorac inside the cell; and evidence that TIR1 receptors respond to quinclorac or whether there are other signaling proteins involved in the process. Therefore, complementary studies may help to understand the biochemical and physiological activity of quinclorac, thus, providing evidence that the existing theories up to this moment are inter-related, as suggested here (Figure 3).

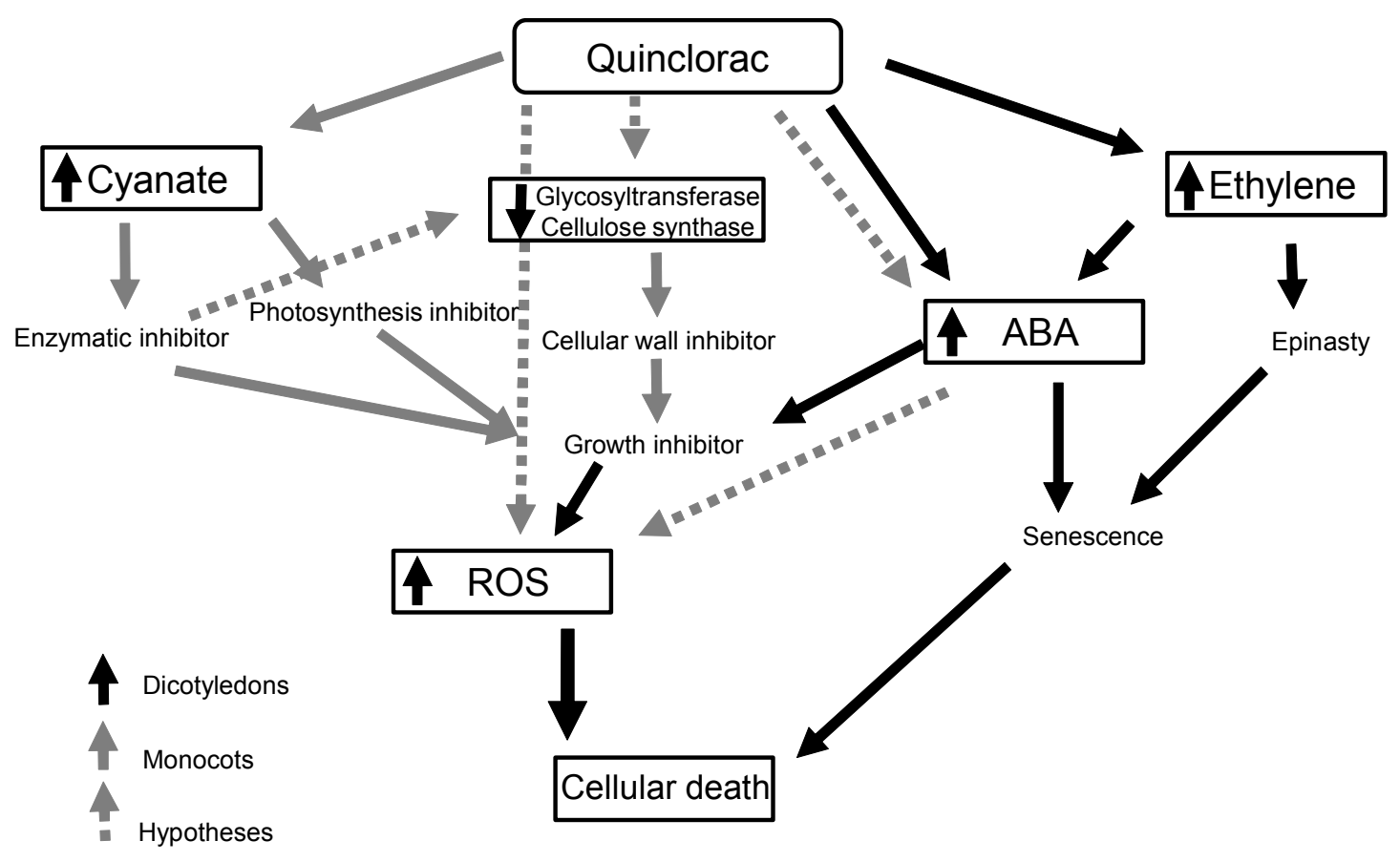

Figure 3 - Integrating hypothesis of the mode of action of quinclorac. The black arrows indicate the mode of action on dicotyledons, and the gray arrows, the mode of action on monocots. The dotted grey arrows indicate action pathways that need further evidence. 
Understanding the sensitivity and the physiological responses of weeds to quinclorac may offer basic information for their management and the possibility of optimized use of this herbicide. The resistance of plants to quinclorac may be associated to the sensitivity on the site of action on the cell wall synthesis (Koo et al., 1997), or the ability to detoxify cyanate (Abdallah et al., 2006), or the increased activity and/or synthesis of antioxidant enzymes (Sunohara \& Matsumoto, 2004). Therefore, elucidating the mechanism and the mode of action of quinclorac is a fundamental step to elaborate resistance prevention and management strategies.

\section{ACKNOWLEDGEMENTS}

To CNPQ and CAPES, for the support to the researchers. To professors M.M. Trezzi (UTFPR) and N.D. Kruse (UFRGS), for the suggestions made to an initial draft of this text.

\section{LITERATURE CITED}

ABDALLAH, I. et al. Mechanism of resistance to quinclorac in smooth crabgrass (Digitaria ischaemum). Pest. Biochem. Physiol., v. 84, n. 1, p. 38-48, 2006.

ALONSO-SIMÓN, A. et al. Habituation of bean (Phaseolus vulgaris) cell cultures to quinclorac and analysis of the subsequent cell wall modifications. Ann. Bot., v. 101, n. 9, p. 1329-1339, 2008.

BADESCU, G. O.; NAPIER, R. M. Receptors for auxin: will it all end in TIRs?. Trends Plant Sci., v. 11, n. 5, p. 217-223, 2006.

BASHLINE, L. et al. The endocytosis of cellulose synthase in Arabidopsis is dependent on mu2, a clathrin mediated endocytosis adaptin. Plant Physiol., v. 163, n. 1, p. 150-160, 2013.

BOND, J. A.; WALKER, T. W. Effect of postflood quinclorac applications on commercial rice cultivars. Weed Technol., v. 26, n. 2, p. 183-188, 2012.

BOWLER, C. et al. Superoxide-dismutase and stress tolerance. Ann. Rev. Plant Physiol. Plant Molec. Biol., v. 43, n. 1, p. 83-116, 1992.

BRAUN, N. et al. Conditional repression of AUXIN BINDING PROTEIN1 reveals that it coordinates cell division and cell expansion during postembryonic shoot development in Arabidopsis and Tobacco. Plant Cell, v. 20, n. 10, p. 2746-2762, 2008.

Planta Daninha, Viçosa-MG, v. 34, n. 2, p. 393-402, 2016
CHEVALIER, L. et al. Subcompartment localization of the side chain xyloglucan-synthesizing enzymes within Golgi stacks of tobacco suspensioncultured cells. Plant J., v. 64, n. 6, p. 977-989, 2010.

COSGROVE, D. J. Wall structure and wall loosening. A look backwards and forwards. Plant Physiol., v. 125, n. 1, p. 131-134, 2001.

DEBOLT, S. et al. Nonmotile cellulose synthase subunits repeatedly accumulate within localized regions at the plasma membrane in Arabidopsis hypocotyl cells following 2,6dichlorobenzonitrile treatment. Plant Physiol., v. 145, n. 2, p. 334-338, 2007.

DHARMASIRI, N. et al. The F-box protein TIR1 is an auxin receptor. Nature, v. 435, n. 1, p. 441-445, 2005.

DRIOUICH, A. et al. Golgi-mediated synthesis and secretion of matrix polysaccharides of the primary cell wall of higher plants. Frontiers Plant Sci., v. 3, n. 79, p. 1-15, 2012.

FERREIRA, E. A. et al. Características micromorfológicas de biótipos de capim arroz resistente e suscetível ao quinclorac. Pesq. Agropec. Bras., v. 47, n. 8, p. 1048-1056, 2012.

GARCÍA-ÂNGULO, P. et al. Cellulose biosynthesis inhibitors: comparative effect on bean cell cultures. Inter. J. Molec. Sci., v. 13, n. 3, p. 3685-3702, 2012.

GROSSMANN, K. The mode of action of auxin herbicides: a new ending to a long, drawn out story. Trends Plant Sci., v. 5 , n. 12 , p. $506-508,2000$.

GROSSMANN, K.; KWIATKOWSKI, J. The mechanism of quinclorac selectivity in grasses. Pestic. Biochem. Physiol., v. 66, n. 2 , p. $83-91,2000$.

GROSSMANN, K. et al. Auxin herbicides induce H2O2 overproduction and tissue damage in cleavers (Galium aparine L.). J. Exper. Bot., v. 52, n. 362, p. 1811-1816, 2001.

GROSSMANN, K. News from old compounds: the mode of action of auxin herbicides. In: VOSS, G.; RAMOS, G. Chemistry of crop protection: progress and prospects in science and regulation. Weinheim: Wiley, 2003. p. 131-142.

GROSSMANN, K. Auxin herbicides: current status of mechanism and mode of action. Pest Manage. Sci., v. 66, n. 2, p. 113-120, 2010.

HANSEN, H.; GROSSMANN, K. Auxin-induced ethylene triggers abscisic acid biosynthesis and growth inhibition. Plant Physiol., v. 124, n. 3, p. 1437-1448, 2000.

HOLLAND, N. et al. A comparative analysis of the plant cellulose synthase (CesA) gene family. Plant Physiol., v. 123, n. 1, p. 1313-1324, 2000. 
KEPINSKI, S.; LEYSER, O. The Arabidopsis F-box protein TIR1 is an auxin receptor. Nature, v. 435, n. 7041, p. 446-451, 2005.

KOO, S. J. et al. Quinclorac-induced electrolyte leakage in seedling grasses. Weed Sci., v. 42, n. 1, p. 1-7, 1994.

KOO, S. J. et al. 3,7-dichloroquinolinecarboxylic acid inhibits cell-wall biosynthesis in maize roots. Plant Physiol., v. 112, n. 3, p. 1383-1389, 1996.

KOO, S. J. et al. Mechanism of action and selectivity of quinclorac in grass roots. Pestic. Biochem. Physiol., v. 57, n. 1, p. 44-53, 1997.

KRAFT, M. et al. Indole-3-acetic acid and auxin herbicides up-regulate 9-cisepoxycarotenoid dioxygenase gene expression and abscisic acid accumulation in cleavers (Galium aparine): interaction with ethylene. J. Exper. Bot., v. 58, n. 6, p. 1497-1503, 2007.

LIANG, W. S. Drought stress increases both cyanogenesis and $\beta$-cyanoalanine synthase activity in tobacco. Plant Sci., v. 165, n. 5, p. 1109-1115, 2003.

MCMAHON, J. M. et al. Molecular control of ethylene production by cyanide in Arabidopsis thaliana. Physiol. Plant., v. 109, n. 2, p. 180-187, 2000.

MANSOORI, N. et al. KORRIGAN1 interacts specifically with integral components of the cellulose synthase machinery. Plos One, v. 9, n. 11, p. 1-9, 2014.

MITO, N. et al. Effects of hormone-type herbicides on proton excretion and anthocyanin synthesis of mung bean hypocotyl sections. J. Weed Sci. Technol., v. 35, n. 4, p. 332-339, 1990.

MITO, N. et al. Competition by auxin-type herbicides for NAA binding to maize auxin binding protein: comparison with in vivo auxin activity. J. Pestic. Sci., v. 16, n. 1, p. 435-439, 1991.

NAVROT, N. et al. Reactive oxygen species generation and antioxidant systems in plant mitochondria. Physiol. Plant., v. 129, n. 1, p. 185-195, 2007.

O'LOONEY, N.; FRY, S. C. The novel herbicide oxaziclomefone inhibits cell expansion in maize cell cultures without affecting turgor pressure or wall acidification.

New Phytol., v. 168, n. 2, p. 323-329, 2005.

PAREDEZ, A. R. et al. Visualization of cellulose synthase demonstrates functional association with microtubules. Science, v. 312, n. 1, p. 1491-1495, 2006.
PENG, L. et al. The experimental herbicide CGA 3252615 inhibits synthesis of crystalline cellulose and causes accumulation of non-crystalline $\beta$ - $(1,4)$-glucan associated with CesA protein. Plant Physiol., v. 126, n. 3, p. 981-992, 2001.

PENG, L. et al. Sitosterol-beta-glucoside as primer for cellulose synthesis in plants. Science, v. 295, n. 1, p. 147-150, 2002.

RICHMOND, T. A.; SOMERVILLE, C. R. The cellulose synthase superfamily. Plant Physiol., v. 124, n. 1, p. $495-498,2000$.

SIEGIEN, I.; BOGATEK, R. Cyanide action in plants - from toxic to regulatory. Acta Physiol. Plant., v. 28, n. 5 , p. 483-497, 2006.

SUNOHARA, Y.; MATSUMOTO, H. Oxidative injury induced by the herbicide quinclorac on Echinochloa oryzicola Vasing. and the involvement of antioxidative ability in its highly selective action in grass species. Plant Sci., v. 167, n. 3, p. 597-606, 2004.

SUNOHARA, Y.; MATSUMOTO, H. Quinclorac-induced cell death is accompanied by generation of reactive oxygen species in maize root tissue. Phytochemistry, v. 69, n. 12, p. 2312-2319, 2008.

SUNOHARA, Y. et al. Sensitivity and physiological responses of Eleusine indica and Digitaria adscendens to herbicide quinclorac and 2,4-D. Environ. Exper. Bot., v. 68, n. 2, p. 157-164, 2010.

SUNOHARA, Y. et al. Involvement of antioxidant capacity in quinclorac tolerance in Eleusine indica. Environ. Exper. Bot., v. 74, n. 8, p. 74-81, 2011.

TAIZ, L.; ZEIGER, E. Etileno: o hormônio gasoso. In: TAIZ, L.; ZEIGER, E. Fisiologia vegetal. Porto Alegre: Artmed, 2006. p. 541-560.

TALBERT, R. E.; BURGOS, N. R. History and management of herbicide resistant barnyardgrass (Echinochloa crus-galli) in Arkansas rice. Weed Technol., v. 21, n. 2, p. 324-331, 2007.

TAN, X. et al. Mechanism of auxin perception by the TIR1 ubiquitin ligase. Nature, v. 446, n. 1, p. 640-645, 2007.

THIMM, J.C. et al. Celery (Apium graveolens) parenchyma cell walls: cell walls with minimal xyloglucan. Physiol. Plant., v. 116, n. 2, p. 164-171, 2002.

TRESCH, S.; GROSSMANN, K. Quinclorac does not inhibit cellulose (cell wall) biosynthesis in sensitive barnyard grass and maize roots. Pestic. Biochem. Physiol., v. 75, n. 3, p. 73-78, 2003. 
van EERD, L.L. et al. Resistance to quinclorac and ALSinhibitor herbicides in Galium spurium is conferred by two distinct genes. Weed Res., v. 44, n. 5, p. 355-365, 2004.

van EERD, L.L. et al. Physiological and biochemical characterization of quinclorac resistance in a false cleavers (Galium spurium 1.) biotype. J. Agric. Food Chem., v. 53, n. 4, p. 1144-1151, 2005

VANNESTE, S.; FRIML, J. Auxin: a trigger for change in plant development. Cell, v. 136, n. 6, p. 1005-1016, 2009.
WIGHTMAN, R.; TURNER, S. Trafficking of the plant cellulose synthase complex. Plant Physiol., v. 153, n. 2, p. 427-432, 2010.

WILLIAMS, W. et al. Quinclorac: soil behavior and foliar vs. root absorption by torpedograss (Panicum repens).

Weed Sci., v. 18, n. 3, p. 626-633, 2004.

YASUOR, H. et al. Quinclorac resistance: a concerted hormonal and enzymatic effort in Echinochloa phyllopogon.

Pest Manage. Sci., v. 68, n. 1, p. 108-115, 2011. 